\title{
Evaluating THE EFFECT OF OPERATING Pressure ANd Riser Height ON IrRigation WATER APPLICATION UNDER DIFFERENT WiND CONDITIONS IN ETHIOPIA
}

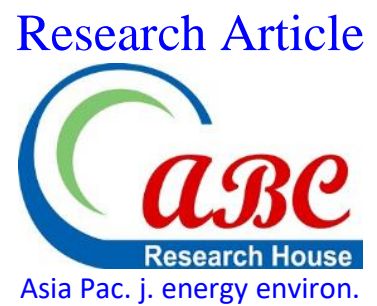

\author{
Dereje Bishaw $^{*}$, Megersa Olumana ${ }^{2}$ \\ ${ }^{1}$ Researcher in Irrigation Engineering; Research \& Training Division, Sugar Corporation, ETHIOPIA \\ ${ }^{2}$ Department of Civil Engineering Sciences, Faculty of Engineering and Built Environment; University of Johannesburg, SOUTH AFRICA \\ *Email for Correspondence: derejebishaw@yahoo.com
}

Abstract

Efficient and effective use of water resource is crucial to increase crop production. This can be achieved through uniform application of water and by reducing application losses. A field experiment was conducted at Wonji/Shoa Sugarcane Plantation (Ethiopia) to study the effect of sprinkler operating pressure and riser height on water distribution uniformity under different wind conditions. Three levels of operating pressure and two levels of sprinkler riser height, under three different wind conditions, were examined during the experiment. From the research evaporation and drift losses ranging from $11.2 \%$ to $16.4 \%$ were determined. Potential application efficiency (PAE) of $47.7 \%$ to $91.3 \%$ and actual application efficiency of low-quarter (AELQ) of $32.9 \%$ to $38.6 \%$ were achieved under various test combinations. Christiansen's coefficient of uniformity (CU) of $71.7 \%$ to $81.7 \%$ and distribution uniformity (DU) of $56 \%$ to $75.7 \%$ were obtained under different test combinations. The results indicated that increase riser height leads to increase in sprinkler water uniformity. Higher sprinkler water uniformity and low application water loss have been encountered during low wind speed condition.

Key words

Uniformity, efficiency, operating pressure, riser height, water loss, wind speed

This article is is licensed under a Creative Commons Attribution-NonCommercial 4.0 International License.

Attribution-NonCommercial (CC BY-NC) license lets others remix, tweak, and build upon work non-commercially, and although the new works must also acknowledge \& be non-commercial.

\section{INTRODUCTION}

Modern irrigation technologies, like sprinkler and trickle irrigation, can result in less water wastage because water is conveyed in pipes and irrigators can control the amount of water applied and its timing more easily which can increase productivity per unit of water (Keller and Bleisner, 1990). Sprinkler irrigation systems have large potential for improving water productivity (water use efficiency) of crops (Kahlown et al., 2007). The basic aim of sprinkler irrigation systems is to apply irrigation water as uniformly as possible to the crop root zone. The uniformity distribution of the applied water depends on factors such as operating pressure, nozzle size, riser height, sprinkler spacing, and wind speed and direction (Keller and Bliesner, 1990; Turjuelo et al., 1999).

In sprinkler irrigation, the water distribution pattern is strongly affected by wind speed and distribution. Consequently, some areas of the field may not receive an adequate amount of irrigation water (Dechmi, 2002). Much work has been done in various countries to describe the effects of wind on sprinkler irrigation systems. Results indicate that the effects, when combined with other environmental factors, are more pronounced in some areas than in others and may vary from region to region under similar wind conditions, with daytime losses as high as 25 percent reported (Marco et al., 1989).

Water application losses, like wind drift, increase as wind speeds increase and droplet sizes decrease. At higher wind speeds, larger droplets can be transported by the wind, and droplets can be transported greater distances (Smajstrla et al., 2002; Smajstrla and Zazueta, 2003). Such losses can be fairly significant if the sprinkler nozzles are located high 
above the crop canopy where they are subjected to higher wind velocities than those that occur close to the canopy because of greater opportunity time for evaporation (Cuenca, 1989; Abo-Ghobar, 1994).

Riser height has a significant effect on sprinkler uniformity especially in windy areas. Wind drift and evaporation losses are lower if sprinklers are located closer to the soil, but this could reduce wetted radius, implying shallower flooding (with possible run-off in sloped areas) and reduces water distribution uniformity (Tarjuelo et al., 1999). As the riser height decrease water application uniformity also increase (Al-Ghobari and Al-Rajh, 2001).

Irrigation systems should be evaluated to establish uniformity of water application and to identify run times that minimize dry areas. Application performance is related to sugarcane yield. Sugarcane growth may be affected due to non-uniform application of water and creation of dry spots. Research conducted by Lecler and Jumman (2009) in South Africa clearly indicates that there are substantial differences in sucrose yield for different uniformities and soil depths (shallow and deep soils) for the same water application. Lopez-Mata et al. (2010) also indicate that an increase in uniformity of water in the soil could result in $4 \%$ increase in yield. Thus, it is possible to increase cane yield and reduce cost of irrigation water by maintaining uniform water application and reducing application water losses (Montazar and Sadeghi, 2008).

Dragline sprinkler irrigation has been operational at Wonji/Shoa Sugar Estate (WSSE) at Wake-Tio and Dodota sites in Ethiopia since 2009. The performance has not been studied well. The high wind speed together with operational pressure and leakage conditions are believed to be the limiting factors for poor water application uniformity in these areas and need major concern. In fact, long year metrological data registered in the area indicated that the average wind speed was higher than $2.5 \mathrm{~m} / \mathrm{s}$. Preliminary field observation indicated that the growth of the sugarcane is not uniform. This may be one indication for non-uniform application of water in the area. This study has been initiated with a view to identify optimal operating pressure and riser height combination for the prevailing wind conditions. The study contributes to the improvement of the existing sprinkler irrigation in saving of water and energy.

\section{Materials AND MEthods}

\section{Experimental site}

The experiment was conducted at Wonji/Shoa Sugar Estate out growers cane plantation fields, located in the central rift valley of Ethiopia. It is located at an elevation of $1550 \mathrm{~m}$ above sea level with latitude of $8^{\circ} 24^{\prime} \mathrm{N}$ and longitude of $39^{\circ} 21^{\prime}$ E. The climate of the study area is tropical with seasonal wet and dry seasons. There is little rain in March and April. The main rainy season stretches from the beginning of July up to the end of September. The mean annual minimum and maximum daily air temperatures are $12.6{ }^{\circ} \mathrm{C}$ and $28.5{ }^{\circ} \mathrm{C}$, respectively. The yearly average precipitation and wind speed are $768 \mathrm{~mm}$ and $2.81 \mathrm{~m} / \mathrm{s}$, respectively. The average relative humidity is $53 \%$. Average ETo value of the area estimated by Penman-Monteith equation (Allen et al., 1998) is $5.36 \mathrm{~mm} /$ day. The irrigation system used in the study area is dragline sprinkler (an overhead sprinkler system, where sprinklers are connected by means of portable hoses and permanent pipes to a pressurized water supply). Laterals of the irrigation system are spaced $54 \mathrm{~m}$ apart and the riser valves are placed at an interval of $18 \mathrm{~m}$ on the lateral. Height of the risers is 4 meters above the ground, which is uniform throughout the sugarcane growth stages. The whole sprinkler system of the Estate uses single brass nozzle of diameter $4.4 \mathrm{~mm}$. Irrigation is practiced for 9 to 10 months except July, August and September depending on the weather condition. The soils in the study area are described as loams, silty loams and clay loams formed from volcanic derived colluviums and alluvium on plains and terraces.

\section{Experimental design}

The effects of riser height and operating pressure on sprinkler irrigation performance (uniformity coefficient, distribution uniformity and application efficiency) were investigated under different prevailing wind conditions. The field uniformity was evaluated using graduated plastic catch cans whereby 36 cans were placed at intervals of 3 $\mathrm{m}$ in an area bound by four sprinklers. For the analysis of performance parameters, the sprinkler spacing was taken as $18 \mathrm{~m} \times 18 \mathrm{~m}$ as practiced by the Estate. The catch-can spacing (centre to centre) used for this study was $3 \mathrm{~m} \times 3 \mathrm{~m}$, and was placed $1.5 \mathrm{~m}$ from the boundary lines of the block. The catch can opening diameter was $7.7 \mathrm{~cm}$ and $20 \mathrm{~cm}$ height placed on a level ground surface. Each catch can was placed on plastic pegs of height $22.4 \mathrm{~cm}$. The field tests were conducted on sugarcane fields immediately after harvesting, where vegetation could not influence water distribution in the catch cans. Three levels of lateral operating pressures (2.5, 3.0 and 3.5 bar) and two levels of riser heights $(2.5 \mathrm{~m}$ and $4.0 \mathrm{~m}$ ) were tested under three wind speed conditions (morning, mid-day and late afternoon) in which the wind speed were expected variable. The pattern of distribution was evaluated by measuring the precipitation in catch cans at different points in the sprinkled area. Field evaluations were conducted at two farms and several catch can tests were conducted. Wind speed, humidity and temperature data were recorded during each test from a metrological station located about $2 \mathrm{~km}$ distance from the experimental site. 
Moreover, to estimate the volume of water lost by evaporation in catch cans, four catch cans, with $1 \mathrm{~cm}$ depth of water, were placed on each test field outside the testing area, both during the field test and during the reading process.

\section{Data analysis and interpretation}

Evaporation and wind drift losses were computed using (Trimmer, 1987) equation as cited by (Cuenca (1989) which was developed based on the regression relationships and the geometry of the Frost and Schwalen Nomograph. It is given as:

$$
\mathrm{E}=\left[1.98(\mathrm{D})^{-0.72}+0.22\left(\mathrm{e}_{\mathrm{s}}-\mathrm{e}_{\mathrm{a}}\right)^{0.63}+3.6 \times 10^{-4}(\mathrm{~h})^{1.16}+0.14(\mathrm{u})^{0.7}\right]^{4.2}
$$

where $\mathrm{E}$ is evaporation and wind drift $(\%), \mathrm{D}$ is nozzle diameter $(\mathrm{mm}), \mathrm{h}$ is nozzle operating pressure $(\mathrm{kPa}), \mathrm{U}$ is wind velocity $(\mathrm{m} / \mathrm{s})$ and $\mathrm{e}_{\mathrm{s}}$ - $\mathrm{e}_{\mathrm{a}}$ is vapor pressure deficit $(\mathrm{kPa})$.

Potential Application Efficiency (PAE) (\%) was calculated by the following formula (Merriam et al., 1983).

$$
\mathrm{PAE}=\left[\frac{\text { average depth of water received }}{\text { average depth of water applied at nozzles }}\right] 100
$$

Actual Application Efficiency of Low Quarter (AELQ) (\%) was calculated as (Merriam et al., 1983):

$$
\mathrm{AELQ}=\left[\frac{\text { average low }- \text { quarter depth of water infiltrated and stored }}{\text { average depth of water applied }}\right] 100
$$

Application uniformity was evaluated using Christiansen uniformity coefficient (CU). CU is commonly used in agricultural sprinkler uniformity assessment and is expressed as (Cuenca, 1989):

$$
\mathrm{CU}=100\left[1-\sum_{i=1}^{n} \frac{a b s\left(x_{i}-\bar{x}\right)}{n \bar{x}}\right]
$$

where CU is Christiansen Uniformity Coefficient (\%), $x_{i}$ is individual depth caught in can (mm), $\bar{x}$ is mean depth caught $(\mathrm{mm})$ and $\mathrm{n}$ is number of cans.

Distribution uniformity was defined as (Burt et al., 1997):

$$
\mathrm{DU}=100\left[\frac{\mu_{\mathrm{LQ}}}{\mu}\right]
$$

where DU is distribution uniformity (\%), $\mu_{\mathrm{LQ}}$ is average applied depth of the lowest quarter and $\mu$ is grand mean applied depth.

\section{Results AND Discussion}

\section{Evaporation and wind drift losses}

Average results of several tests for evaporation and wind drift losses based on the empirical loss equation are presented in Tables 1. As can be seen from Table 1, evaporation and drift losses increased from 11.6 to $16.4 \%$ when the operating pressure and air temperature increased. It is found that evaporation and drift losses increase as operating pressure increase. These losses are dependent on the prevalent hydraulic (operating pressure) and climatic conditions (air temperature and wind speed) (Abo-Ghobar, 1993; Yacoubi et al., 2010; Yacoubi et al., 2012). According to Martinez-Cob et al. (2005) as cited by Zapata et al. (2007), the threshold value for evaporation and drift losses in sprinkler irrigation was $\leq 20 \%$. Fortunately, the results obtained in this study were below the threshold value at all operating pressures considered. 
Table 1: Evaporation and drift losses under various operating pressure and climatic conditions

\begin{tabular}{ccccc}
\hline $\begin{array}{c}\text { Operating } \\
\text { pressure }(\mathrm{bar})\end{array}$ & $\begin{array}{c}\text { Wind } \\
\text { speed }(\mathrm{m} / \mathrm{s})\end{array}$ & $\begin{array}{c}\text { Air } \\
\text { temperature }\left({ }^{\circ} \mathrm{C}\right)\end{array}$ & $\begin{array}{c}\text { Relative } \\
\text { humidity }(\%)\end{array}$ & $\begin{array}{c}\text { Evaporation \& } \\
\text { drift losses }(\%)\end{array}$ \\
\hline 2.5 & 4.20 & 33.4 & 26 & 11.59 \\
3.0 & 4.77 & 31.6 & 37 & 11.83 \\
3.5 & 4.72 & 33.6 & 23 & 16.35 \\
\hline
\end{tabular}

Operating pressure and wind speed are the predominant factors that affect losses from sprinkler system (AboGhobar, 1993). As reported by Molle et al. (2011), losses due to evaporation represented $30-50 \%$ of total losses; the remaining $50-70 \%$ was due to wind causing small droplets to drift outside the target zone. Playan et al. (2005) also reported evaporation and drift losses of $15.4 \%$ and $8.5 \%$ for solid-set system during day and night irrigations, respectively. Several authors have reported that evaporation and drift losses were dependent on operating and climatic conditions, primarily on wind speed (Kamey and Podmore, 1984; Al-Jumaily and Abdul-Kader, 2008).

\section{Wetted diameter}

The average wetted diameters measured from different testing combinations ranged from $21.6 \mathrm{~m}$ (for $2.5 \mathrm{bar}$ operating pressure and $4.0 \mathrm{~m}$ riser height at mid-day test) to $28.5 \mathrm{~m}$ (for 3.5 bar operating pressure and $2.5 \mathrm{~m}$ riser height at morning test) (Table 2). The average wetted diameter increased as operating pressure increased up to the optimum design operating pressure (3.0 bar) and decreased as wind speed and riser height increased. This result is in line with the study made by Shauq (2003) who reported that the wetted diameter increased as the operating pressure increased and decreased as wind speed increased. Contrary to this study, Montero et al. (2000) reported that wetted diameter increased as riser height increased. The difference may be due to the variations in wind speed and direction, whereas effect of other environmental factors on the wetted diameter was minor.

Table 2: Wetted diameters for different test combinations $(\mathrm{m})$

\begin{tabular}{|c|c|c|c|c|c|}
\hline \multirow[b]{2}{*}{ operating pressure } & \multirow[b]{2}{*}{ Wind condition } & \multicolumn{2}{|c|}{$2.5 \mathrm{~m}$ riser height } & \multicolumn{2}{|c|}{$4 \mathrm{~m}$ riser height } \\
\hline & & $\begin{array}{l}\text { wind speed } \\
(\mathrm{m} / \mathrm{s})\end{array}$ & $\begin{array}{c}\text { Wetted } \\
\text { diameter }(\mathrm{m})\end{array}$ & $\begin{array}{l}\text { wind speed } \\
(\mathrm{m} / \mathrm{s})\end{array}$ & $\begin{array}{c}\text { Wetted } \\
\text { diameter } \\
(\mathrm{m})\end{array}$ \\
\hline \multirow{3}{*}{2.5 bar } & Morning & 2.50 & 25.2 & 2.28 & 24.8 \\
\hline & Mid-day & 2.90 & 24.3 & 2.96 & 21.6 \\
\hline & Late afternoon & 1.76 & 25.7 & 1.73 & 23.4 \\
\hline Mean & & & 25.1 & & 23.1 \\
\hline \multirow{3}{*}{3.0 bar } & Morning & 2.38 & 27.4 & 2.26 & 25.7 \\
\hline & Mid-day & 3.29 & 26.8 & 4.42 & 27.0 \\
\hline & Late afternoon & 2.32 & 28.1 & 2.02 & 27.2 \\
\hline Mean & & & 27.4 & & 26.6 \\
\hline \multirow{3}{*}{3.5 bar } & Morning & 1.96 & 28.5 & 1.66 & 25.1 \\
\hline & Mid-day & 3.75 & 26.9 & 4.13 & 27.9 \\
\hline & Late afternoon & 1.43 & 27.3 & 2.30 & 27.8 \\
\hline Mean & & & 27.6 & & 26.9 \\
\hline
\end{tabular}

Gabriel et al. (2011) noted that an increase in pressure up to optimum pressure (from 2.5 to 3.0 bar) of a sprinkler results in a larger wetted radius. If the pressure is too high, the droplets break up excessively and misting occurs. Fine droplets fall close to the sprinkler causing poor overlap, increasing losses from wind and evaporation. As discussed by Ahaneku (2010), distance that sprinkler throws water is highly dependent on operating pressure.

The design of sprinkler system of Wonji/Shoa Sugar Estate (WSSE) at Wake-Tio and Dodota sites involves an overlap of $65 \%$ of the wetted diameter in spacing. Failure of some of the sprinkler settings during the test to meet the minimum wetted diameter requirements of $65 \%$ between sprinklers was due to the effect of wind speed. The wetting diameter at 2.5 bar of operating pressure for both riser heights did not satisfy the required minimum wetted diameter. 
Potential application efficiency

The results for potential application efficiency (PAE), coefficient of uniformity (CU) and distribution uniformity (DU) for different tests are presented in Table 3. The potential application efficiency (PAE) was determined from average catch can data. The purpose of determining PAE was to determine the loss of water as a result of evaporation and wind. The result indicated wide ranges, $47.7 \%$ to $91.3 \%$ (Table 3). The lowest PAE was recorded for operating pressure of 3.0 bar and riser height of $4.0 \mathrm{~m}$ and the highest PAE was recorded for operating pressure of 3.5 bar and riser height of $4.0 \mathrm{~m}$. The highest value of PAE indicated that the average depth emitted from the sprinkler compared to the average depth recorded on the ground was similar. PAE of $47.7 \%$ means $52.3 \%$ of the applied water was loss between the emitter and the ground surface. This was due to the effect of higher wind velocities that occurred during the test. Some test combinations clearly showed that the PAE decreased as the riser height decreased and the other half showed the opposite. The variation may be due to the effect of wind velocity. Similar result was reported by ElShafei et al. (2008) as PAE was increased with the increase of riser height above the ground.

Table 3: Average PAE, CU and DU values for different sprinkler combinations for four sprinklers test (\%)

\begin{tabular}{|c|c|c|c|c|c|c|c|c|c|}
\hline \multirow[b]{2}{*}{ Operating pressure } & \multirow[b]{2}{*}{ Wind condition } & \multicolumn{4}{|c|}{$2.5 \mathrm{~m}$ riser height } & \multicolumn{4}{|c|}{$4.0 \mathrm{~m}$ riser height } \\
\hline & & $\begin{array}{l}\text { wind } \\
\text { speed } \\
(\mathrm{m} / \mathrm{s})\end{array}$ & PAE & $\mathrm{CU}$ & DU & $\begin{array}{l}\text { wind } \\
\text { speed } \\
(\mathrm{m} / \mathrm{s})\end{array}$ & PAE & $\mathrm{CU}$ & DU \\
\hline \multirow{6}{*}{2.5 bar } & Morning & 2.50 & 78.70 & 79.00 & 70.00 & 2.28 & 80.00 & 74.30 & 65.30 \\
\hline & Mid-day & 2.90 & 64.30 & 72.00 & 56.00 & 2.96 & 75.00 & 71.70 & 61.00 \\
\hline & Late afternoon & 1.76 & 79.30 & 73.30 & 62.00 & 1.73 & 79.00 & 79.00 & 71.30 \\
\hline & Mean & 2.39 & 74.10 & 74.77 & 62.67 & 2.32 & 78.00 & 75.00 & 65.87 \\
\hline & St. dev & 0.58 & 8.49 & 3.72 & 7.02 & 0.62 & 2.65 & 3.70 & 5.17 \\
\hline & CV $(\%)$ & 24.23 & 11.46 & 4.98 & 11.21 & 26.52 & 3.39 & 4.93 & 7.85 \\
\hline \multirow{6}{*}{3.0 bar } & Morning & 2.38 & 75.30 & 80.70 & 73.30 & 2.26 & 85.70 & 81.70 & 75.70 \\
\hline & Mid-day & 3.29 & 63.30 & 75.30 & 65.00 & 4.42 & 47.70 & 73.30 & 63.70 \\
\hline & Late afternoon & 2.32 & 70.30 & 76.70 & 68.30 & 2.02 & 52.30 & 80.70 & 73.00 \\
\hline & Mean & 2.66 & 69.63 & 77.57 & 68.87 & 2.90 & 61.90 & 78.57 & 70.80 \\
\hline & St. dev & 0.54 & 6.03 & 2.80 & 4.18 & 1.32 & 20.74 & 4.59 & 6.30 \\
\hline & CV $(\%)$ & 20.41 & 8.66 & 3.61 & 6.07 & 45.58 & 33.50 & 5.84 & 8.89 \\
\hline \multirow{6}{*}{3.5 bar } & Morning & 1.96 & 87.30 & 77.70 & 67.30 & 1.66 & 91.30 & 79.30 & 71.30 \\
\hline & Mid-day & 3.75 & 69.70 & 73.00 & 64.00 & 4.13 & 57.30 & 73.00 & 66.70 \\
\hline & Late afternoon & 1.43 & 81.00 & 75.70 & 67.30 & 2.30 & 62.00 & 79.30 & 70.00 \\
\hline & Mean & 2.38 & 79.33 & 75.47 & 66.20 & 2.70 & 70.20 & 77.20 & 69.33 \\
\hline & St. dev & 1.22 & 8.92 & 2.36 & 1.91 & 1.28 & 18.42 & 3.64 & 2.37 \\
\hline & CV $(\%)$ & 51.08 & 11.24 & 3.13 & 2.88 & 47.54 & 26.24 & 4.71 & 3.42 \\
\hline
\end{tabular}

Variation in PAE is strongly correlated with wind speed, CU and DU in both operating pressures and riser heights. The wind speed is higher in day time in the study area (Table 3). For all test combinations, the PAE value obtained during midday time test was lower than the values obtained during morning and late afternoon time tests. This was because of the wind speed in which it reached at peak during this time and the water applied to the crop was affected by drift losses. Magwenzi (2000) noted that due to wind distortions, wide sprinkler spacings, low pressures and unequal stand-times he found an application efficiency of $49 \%$ to $88 \%$ for dragline sprinkler. For sprinkler irrigation the recommended minimum application efficiency is 70\% (Beer and Bhembe, 2008). About 50\% of PAE results obtained were below the recommended.

\section{Actual application efficiency of low quarter}

The low quarter depth of water infiltrated and stored in the effective root zone was used for the determination of the actual application efficiency of the low quarter. Gravimetric soil moisture was measured at depths of 0-30 and 30$60 \mathrm{~cm}$ before and after irrigation to determine the water infiltrated and stored in the root zone. The value obtained ranges from $32.9 \%$ (for 2.5 bar operating pressure and $2.5 \mathrm{~m}$ riser height) to $38.6 \%$ (for 3.0 bar operating pressure and 
of $4.0 \mathrm{~m}$ riser height) (Table 4). This implied that the water loss due to deep percolation (below the effective root zone) and surface evaporation from the sugarcane field was $62.4 \%$ to $67.1 \%$. Several authors illustrated that in order to improve irrigation system performance and to reduce gap between PAE and AELQ; attention should be paid for the sprinkler management aspect such as maintaining the optimum operating pressure and irrigating during low wind speed (Ismail et al., 1996; Lecina et al., 2005; Nasab et al., 2007).

Table 4: AELQ determined from four sprinklers test (\%)

\begin{tabular}{cccc}
\hline & $\begin{array}{c}2.5 \text { bar operating } \\
\text { pressure }\end{array}$ & $\begin{array}{c}3.0 \text { bar operating } \\
\text { pressure }\end{array}$ & $\begin{array}{c}3.5 \text { bar operating } \\
\text { pressure }\end{array}$ \\
\hline $2.5 \mathrm{~m}$ riser height & 32.9 & 38.6 & 34.8 \\
$4.0 \mathrm{~m}$ riser height & 35.1 & 37.5 & 34.3 \\
\hline
\end{tabular}

\section{Water application uniformity}

The results for the coefficient of uniformity (CU) and distribution uniformity (DU) for different sprinkler combinations for four sprinklers are presented in Table 3. CU of $71.7 \%$ to $81.7 \%$ and DU of $56 \%$ to $75.7 \%$ were achieved. Uniformity increased as operating pressure increased from 2.5 to 3.0 bars and decreased as operating pressure increased from 3.0 to 3.5 bars. High uniformity was obtained in low wind speed conditions and generally mid-day test results were lower than morning and late afternoon tests because of high wind speed occurred at this time. Moazed et al. (2010) and Yacoubi et al. (2012) reported that water distribution uniformity coefficient decreased with increase of wind velocity and with decrease in operating pressure below the optimum operating pressure (Gabriel et al., 2011). The uniformity also improved as riser height increased. Montero et al. (2000) and El-Shafei et al. (2008) reported that uniformity coefficient increased with increase of riser height above the ground. In contrast with this, Al-Ghobari and Al-Rajhi (2001) noted that application uniformity increased as riser height decreases. The majority of the test combinations had a CU and DU lower than the recommended $84 \%$ and $75 \%$ by Keller and Bliesner (1990).

Variation in CU across the irrigation events is not correlated with wind speed whereas variation in DU is weakly correlated with wind speed in $2.5 \mathrm{bar}$ and $2.5 \mathrm{~m}$ riser height combination. In contrast to this, variations in CU and DU across the irrigation events are strongly correlated with wind speed in all test combinations. In addition, variation in CU is strongly correlated with DU in all test combinations. As asserted by Merkley and Allen (2004) occasionally wind can help improve uniformity as the randomness of wind turbulence and gusts contribute to smoothening out distribution patterns. This was shown in some test combinations in which uniformity increased with increases in wind speed. As reported by Tarjuelo et al. (1999) irrigation uniformity is less affected by wind speed than by high pressures in solid set sprinkler system.

\section{Conclusions}

The irrigation system must be managed correctly and effectively in order to improve application efficiency and water application uniformity. To achieve this close attention has to be paid to performance of the system. The system needs regular evaluation to avoid system management problems. From the results of the study it is clear that special attention should be given for the system uniformity. Evaporation and drift losses were high as the riser height increased. These losses were exaggerated as wind speed increased. At lower riser heights, the wetting diameter is at acceptable range that is within the design achievable range. The wetted diameter increased as wind speed and riser height increased. So it is important to irrigate sugarcane fields during low wind speed conditions to satisfy the recommended design overlapping of the system. Riser height of $2.5 \mathrm{~m}$ resulted in lower water application efficiencies as compared to $4.0 \mathrm{~m}$ riser height, even if evaporation and drift losses were low. Moreover, high application uniformity is achieved during morning and late afternoon times when the wind speed is lower.

The study guarantied high application uniformity, efficiency and wetted diameter under low wind speed conditions. In relation to this by taking into account evaporation and drift losses, Wonji/Shoa Sugar Estate is strongly recommended to operate the system at low wind speed to improve water distribution and to efficiently utilize the available water. To improve efficiency and uniformity the system needs regular maintenance and proper operation especially maintaining the design operating pressure.

\section{ACKNOWLEDGEMENTS}

We would like to thank the Research and Training division and staffs of the Ethiopian Sugar Corporation for providing the necessary support during data collection and analysis. 


\section{REFERENCES}

Abo-Ghobar, M., 1993. Evaporation and drift losses from sprinkler irrigation systems under hot and dry conditions. Journal of King Saud University, 5 (2): 153-164.

Abo-Ghobar, M., 1994. The effect of riser height and nozzle size on evaporation and drift losses under arid conditions. Journal of King Saud University, 6 (2): 191-202.

Ahaneku, I.E., 2010. Performance evaluation of portable sprinkler irrigation system in Llorin, Nigeria. Indian Journal of Science and Technology, 3(7), 853-857.

Al-Ghobari, M. H., Al-Rajh, A. A., 2001. The influence of nozzle and riser characteristics on sprinkler water distribution under dry climate. Res. Bult., No. (109), Res. Cent. Coll. of Agri., King Saud Univ., pp. (5-25).

Al-Jumaily, K. K., Abdul-Kader, S., 2008. Spray losses in sprinkler irrigation systems in Iraq. Twelfth International Water Technology Conference, IWTC12 2008 Alexandria, Egypt.

Allen, R.G., Pereira, L.S., Raes, D., Smith, M., 1998. Crop evapotranspiration-Guidelines for computing crop water requirements. FAO Irrigation and drainage paper 56. Food and Agriculture Organization of the United Nations, Rome, Italy.

Beer, T., Bhembe, B., 2008. Usuthu Mutwe farmer association report. Swaziland Technical Audit of Farmers Association. Mbabane, Swaziland.

Burt, C.M., Clemmens, A.J., Strelkoff, T.S. Solomon, K.H., Bliesner, R.D., Hardy, L.A., Howell, T.A., Eisenhauer, D.E., 1997. Irrigation Performance Measures: Efficiency and uniformity. Journal of Irrigation and Drainage Engineering. 123(6), $423-442$.

Cuenca, R., 1989. Irrigation system design. An engineering approach. Prentice Hall, Englewood Cliffs, New Jersey 07632.

Dechmi, F., 2002. Water management in sprinkler irrigation systems in the Ebro Valley: Current situation and scenario simulations. A Ph.D. Dissertation Presented to Universitat de lleida. Zaragoza, Spain.

El-Shafei, A., Allam, K. A., Zin El-Abedin, T. K., 2008. Heterogeneity analysis of sprinkler irrigation in peanut fields. Irrigation and Drainage. Misr Journal of Agricultural Engineering, 25(1): 58- 86.

Gabriel, S., Ezra, P., Oniward, S., Tendai, M., 2011. Performance of $4 \mathrm{~mm}$ impact sprinklers at different spacing within acceptable pressure range (250-350 kPa). International Journal of Engineering Science and Technology (IJEST), Vol.3 No.3. ISSN: 0975-5462.

Ismail, Samir, M., Metwafly, Al., Sabbah, M. A., 1996. Irrigation systems evaluation in desert farming. Desert Development Center (DDC), American University in Cairo (AUC), Egypt.

Kahlown, M. A., Raoof, A., Zubair, M., Kemper, W. D., 2007. Water use efficiency and economic feasibility of growing rice and wheat with sprinkler irrigation in the Indus Basin of Pakistan. Agricultural Water Management (87) $292-298$.

Kamey, B. W., Podmore, T. H., 1984. Performance of stationary gun irrigation systems. Journal of Irrigation and Drainage Engineering 110:75-87.

Keller, J., Bliesner, R.D., 1990. Sprinkler and trickle irrigation. Van Nestrand Reinhold. New York.

Lecina, S., Playan, E., Isidoro, D., Dechmi, F., Causape, J., Faci, J.M., 2005. Irrigation evaluation and simulation at the Irrigation District V of Bardenas (Spain). Agricultural Water Management (73) 223-245. http:/ /dx.doi.org/10.1016/j.agwat.2004.10.007.

Lecler, N.L., Jumman A., 2009. Irrigated sugarcane production functions. Proceeding of South African Sugar Technology Association, 82: $604-607$.

Lopez-Mata, E., Tarjuelo, J.M., de Juan, J.A., Ballesteros, R., Dominguez, A., 2010. Effect of irrigation uniformity on the profitability of crops. Agricultural Water Management (98) 190-198. http:/ /dx.doi.org/10.1016/j.agwat.2010.08.006

Magwenzi, O.E., 2000. Evaluation of irrigation efficiency in the Swaziland sugar industry. Swaziland Sugar Association Extension Services. pp. 151-156. Proceedings of South African Sugar Technology Association, 74.

Marco, A., Humpherys, A.S., Spiess, L.B., Decroix, M., 1989. Annotated Bibliography. The influence of wind on sprinkler irrigation. International Commission on Irrigation and Drainage 48, Nyaya Marc, Chanakyapur, New Delhi -110021.

Merkley, G.P., Allen, R.G., 2004. Sprinkle and trickle irrigation lecture notes, Utah State University, USA.

Merriam, J.L., Shearer, M.N., Burt, C.M., 1983. Evaluating irrigation systems and practices. In: Jensen M.E. Design and operation of farm irrigation systems. Irrigation and Drainage Notes. Michigan, U.S.A.

Moazed, H., Bavi, A., Boroomand-Nasab, S., Naseri, A., Albaji M., 2010. Effects of climatic and hydraulic parameters on water uniformity coefficient in solid set systems. Journal of Sciences. ISSN 1812-5654.

Molle, B., Tomas, S., Hendawi, M., Granier, J., 2011. Evaporation and wind drift losses during sprinkler irrigation influenced by droplet size distribution. Irrigation and Drainage Engineering 61: 240-250. John Wiley \& Sons, Ltd. http://dx.doi.org/10.1002/ird.648

Montazar, A., Sadeghi, M., 2008. Effects of applied water and sprinkler irrigation uniformity on alfalfa growth and hay yield. Agricultural Water Management (95) 1279-1287. http:/ / dx.doi.org/10.1016/j.agwat.2008.05.005

Montero, J., Tarjuelo, J.M., Ortega, J.F., 2000. Heterogeneity analysis of the irrigation in fields with medium size sprinklers, CIGR volume (2) 1682-1130, USA.

Nasab, S.B., Baradanare-Hezave, F., Behzad, M., 2007. Technical evaluation of sprinkler irrigation systems in Akra, Iran. Journal of Applied Sciences 7(21): 3338-3341. ISSN 1812-5654.

Ortega, J.F., Montero, J., Tarjuelo, J.M., de Juan J.A., 2003. Discharge efficiency in sprinkling irrigation: Analysis of the evaporation and drift losses in semi-arid areas, CIGR, USA.

Playan E., Salvador, R., Faci, J.M., Zapata, N., Martinez-Cob, A., Sanchez, I., 2005. Day and night wind drift and evaporation losses in sprinkler solid-sets and moving laterals. Agricultural Water Management (76) 139-159. http:/ /dx.doi.org/10.1016/j.agwat.2005.01.015.

Shauq, A.A., 2003. Evaluation of Chinese rain gun Py1-30 with different nozzle sizes. Pakistan Journal of Water Resources, 7 (2): $15-19$.

Smajstrla, A.G., Boman, B.J., Clark, G.A., Haman, D.Z., Harrison, D.S., Izuno, F.T., Pitts, D.J., Zazueta, F.S., 2002. Efficiencies of Florida agricultural irrigation systems. Florida Cooperative Extension Service, Institute of Food and Agricultural Sciences, University of Florida, BUL247. 
Smajstrla, A.G., Zazueta, F.S., 2003. Evaporation loss during sprinkler irrigation. Florida Cooperative Extension Service, Institute of Food and Agricultural Sciences, University of Florida. BUL290.

Tarjuelo, J.M., Montero, J., Honrubia, F.T., Ortiz, J.J., Ortega, J.F., 1999. Analysis of uniformity of sprinkle irrigation in a semi-arid area. Agricultural Water Management (40) 315-331.

Tarjuelo, J.M., Ortega, J.F., Montero, J., de Juan, J.A., 2000. Modeling evaporation and drift losses in irrigation with medium size impact sprinklers under semi-arid conditions. Agricultural Water Management (43) 263-284.

Yacoubi, S., Zayani, K., Slatni, A., Playan, E., 2012. Assessing sprinkler irrigation performance using field evaluations at the Medjerda Lower Valley of Tunisia. Engineering, 2012, 4, 682-691. http:/ /dx.doi.org/10.4236/eng.2012.410087

Yacoubi, S., Zayani, K., Zapata, N., Zairi, A., Slatni, A., Salvador, R., Playan, E., 2010. Day and night time sprinkler irrigated tomato: Irrigation performance and crop yield. Agricultural Water Management (107) 25-35.

Zapata, N., Playan, E., Martinez-Cob, A., Sanchez, I., Faci, J.M., Lecina, S., 2007. From on-farm solid-set sprinkler irrigation design to collective irrigation network design in windy areas. Agricultural Water Management (87) 187-199. http:/ /dx.doi.org/10.1016/j.agwat.2006.06.018 